\title{
PERANCANGAN ULANG TATA LETAK PASAR JOHAR BARU UNTUK MENGURANGI KEPADATAN LALU LINTAS DALAM PASAR
}

\author{
Helena Sisilia Ratna Soetopo ${ }^{1}$, Hendy Tannady $^{2}$, Filscha Nurprihatin ${ }^{3}$, Panca \\ Jodiawan ${ }^{4}$ \\ 1,2,3,4Program Studi Teknik Industri, Universitas Bunda Mulia, Jakarta \\ e-mail: helenaratna22@gmail.com¹, htannady@bundamulia.ac.id², fnurprihatin@bundamulia.ac.id ${ }^{3}$, \\ pjodiawan@bundamulia.ac.id ${ }^{4}$
}

Received: December 4, 2016; Accepted: Januari 6, 2017

\begin{abstract}
ABSTRAK
Keberadaan pasar tradisional di Indonesia memang masih belum dapat tergantikan oleh pasar modern. Hal ini dapat dicermati dari begitu padatnya lalu lintas atau populasi pelanggan yang hilir mudik dan melakukan transaksi di dalam pasar tradisional. Pasar Johar Baru merupakan salah satu pasar tradisional di Jakarta Pusat, dimana pasar ini diharapkan mampu menjadi salah satu alternatif berbelanja bagi 43.509 penduduk Jakarta Pusat yang bermukim di Kelurahan Johar Baru. Penelitian ini menggunakan pendekatan data mining, khususnya metode Market Based Analysis dalam memetakan hubungan asosiasi dari produk yang dibeli oleh pelanggan, dan kemudian dipetakan tata letak berjualan di dalam pasar yang lebih efektif dan efisien sehingga diharapkan mampu mereduksi kepadatan lalu-lintas di dalam pasar. Hasil dari penelitian adalah mengelompokkan penjual sayuran yang semula tersebar di 17 blok meja menjadi 9 blok meja dan ditempatkan di sisi selatan pasar, mengelompokkan penjual buah-buahan yang semula tersebar di 9 blok meja menjadi 4 blok meja dan ditempatkan di sisi selatan pasar, mengelompokkan penjual ayam yang semula tersebar di 7 blok meja menjadi 5 blok meja dan ditempatkan di sisi barat pasar, mengelompokkan penjual daging yang semula tersebar di 5 blok meja menjadi 4 blok meja dan ditempatkan di sisi utara pasar, mengelompokkan penjual ikan yang semula tersebar di 7 blok meja menjadi 4 blok meja dan ditempatkan di bagian barat pasar, mengelompokkan penjual sembako yang semula tersebar di 13 blok meja menjadi 6 blok meja dan ditempatkan di bagian timur pasar, mengelompokkan penjual tahu dan tempe yang semula tersebar di 7 blok meja menjadi 3 blok meja dan ditempatkan di bagian timur pasar, mengelompokkan penjual kelapa yang semula tersebar di 3 blok meja menjadi 2 blok meja dan ditempatkan di bagian utara pasar, mengelompokkan penjual makanan yang semula tersebar di 8 blok meja menjadi 5 blok meja dan ditempatkan di bagian timur pasar, dan mengelompokkan penjual makanan olahan yang semula tersebar di 4 blok meja menjadi 2 blok meja dan ditempatkan di bagian utara pasar.
\end{abstract}

Kata Kunci: Pasar Johar Baru, Kepadatan Lalu-Lintas, Market Based Analysis

\begin{abstract}
The existance of Traditional Market is still irreplacable even by Modern Market which grow rapidly in this decade. This result comes from an observation showing that a lot of people still come and do transactions in Traditional Market. Johar Baru Market is of Traditional Market located in Central Jakarta. This market is supposed to accomodate 43.509 citizens who live in Administrative Village Johar Baru, Central Jakarta. The research utilizes data mining, particularly Market Basket Analysis methods to find the pattern of product sets association. From analyzed pattern, the research is continued by determining the eficient and efective layout in hope of reducing any congestions occured in Market. The result is to group vegetable sellers which currently spread over 17 blocks into 9 blocks and are placed at south of the market, to group fruit sellers which currently spread over 9 blocks into 4 blocks and are placed at south of the market, to group chicken sellers which currently spread over 7 blocks into 5 blocks and are placed at west of the market, to group meat sellers which currently spread over 5 blocks into 4 blocks and are placed at north of the market, to group fish sellers which currently spread over 7 blocks into 4 blocks and are placed at west of the market, to group primary substance sellers which currently spread over 13 blocks into 6 blocks and are placed at east of the market, to group Tofu and Fermented Soybean sellers which currently spread
\end{abstract}


over 7 blocks into 3 blocks and are placed at east of the market, to group coconut sellers which currently spread over 3 blocks into 2 blocks and are placed at north of the market, to group food sellers which currently spread over 8 blocks into 5 blocks and are placed at east of the market, and to group processed food sellers which currently spread over 4 blocks into 2 blocks and are placed at north of the market.

Keywords: Johar Baru Market, Traffic Density, Market Basket Analysis

\section{PENDAHULUAN}

Menurut Asosiasi Pengusaha Ritel Indonesia (Aprindo) yang dimuat dalam www.marketing.com.id, diketahui bahwa pertumbuhan industri ritel di Indonesia berkisar antara $10-15 \%$ dan ini menjadi indikasi bahwa memang pertumbuhan ritel di Indonesia adalah sangat pesat. Menyikapi hal ini, pasar tradisional perlu terus berbenah agar dapat tetap bersaing dengan pasar modern, salah satu cara yang dapat ditempuh agar tetap dapat bersaing adalah dengan menjaga kepuasan pelanggan. Menurut Fornell (1992) kepuasan pelanggan sangat berhubungan terhadap meningkatnya jumlah pelanggan dan reputasi bisnis. Banyak hal yang dapat dilakukan untuk menciptakan kepuasan pelanggan khususnya pada pasar tradisional, salah satunya adalah dengan meminimumkan jarak tempuh pelanggan di dalam pasar, sehingga lalu-lintas dan pergerakan pelanggan di dalam pasar tidak terlalu padat. Beberapa penelitian terdahulu yang berfokus pada perancangan ulang tata letak adalah penelitian yang dilakukan oleh Pradana dan Cahyono (2014) yang menganalisis tata letak fasilitas terhadap pembangunan apartemen Papilio di Surabaya. Christina dan Liem (2014) melakukan penelitian tata letak fasilitas packaging area pada sebuah industri minyak kelapa dan kelapa sawit. Farieza dkk., (2014) meneliti tata letak fasilitas pada lantai produksi sebuah industri garmen.

Penelitian ini berusaha memberikan usulan untuk meningkatkan kepuasan pelanggan dengan cara meminimumkan kepadatan lalu-lintas didalam pasar, berupa usulan perbaikan tata letak pasar, dimana batasan masalah dalam penelitian adalah tidak adanya pengukuran atas kepuasan pelanggan baik sebelum dan setelah usulan perancangan layout.

\section{TINJAUAN PUSTAKA}

\subsection{Data Mining}

Data mining adalah analisis sekumpulan data yang berjumlah besar dengan tujuan untuk menemukan hubungan tak terduga dan meringkas data dengan cara yang dapat dimengerti dan dapat digunakan oleh pemiliki data (Hand dkk, 2001). Data mining disebut juga sebagai knowledge discovery from data (KDD) karena adanya proses pengolahan sejumlah data menjadi pengetahuan yang berguna (Han dkk, 2012). Intensitas penggunaan data mining semakin meningkat seiring perkembangan zaman. Hal ini didasarkan pada beberapa faktor, antara lain (Larose, 2005):

1. Peningkatan jumlah data yang terkumpul yang sangat pesat

2. Penempatan data dalam suatu pusat penyimpanan data

3. Peningkatan ketersediaan akses data dari navigasi web dan intranet

4. Peningkatan persaingan pasar

5. Peningkatan pesat pada kemampuan komputasi dan kapasitas penyimpanan.

Kegiatan dalam data mining dibagi menjadi dua, yaitu interpretasi dan prediksi (Lusiani, 2011). Kegiatan interpretasi merupakan aktivitas untuk mengidentifikasi pola umum dalam data dan mengekspresikannya melalui aturan dan kriteria yang mudah dipahami oleh para ahli di bidangnya. Kegiatan prediksi merupakan aktivitas yang melibatkan sejumlah variabel independen yang digunakan untuk memperkirakan kejadian di masa yang akan datang. Beberapa tahapan dalam proses data mining adalah sebagai berikut (Han dkk., 2012):

1. Pembersihan data

2. Integrasi data

3. Seleksi data

4. Transformasi data

5. Penggalian data

6. Evaluasi pola

7. Visualisasi pengetahuan 


\subsection{Market Basket Analysis}

Market Basket Analysis merupakan proses untuk menganalisis pola pembelian yang dilakukan oleh pelanggan dengan menemukan hubungan (asosiasi) antara produk-produk yang berbeda yang dibeli oleh setiap pelanggan (Han dkk., 2012). Hasil Market Basket Analysis dapat digunakan untuk berbagai keperluan, salah satunya adalah menentukan alokasi produk dalam pasar sehingga mempermudah pelanggan untuk memilih berbagai produk yang berbeda. Hubungan yang dicari dalam Market Basket Analysis secara formal direpresentasikan sebagai association rules. Tujuan dari penemuan asosiasi ini adalah menemukan produk-produk yang mengimplikasikan keberadaan dari produkproduk yang lain (Surjandari dan Seruni, 2005). Association rule dituliskan dalam persamaan (1) yang menjelaskan pelanggan yang membeli produk $X$ juga membeli produk $Y$, dimana $X$ disebut sebagai antecedent dan $Y$ disebut sebagai consequent (Bermudez dkk., 2016).

$X=>Y$

Hubungan ini kemudian diukur dengan dua parameter pengukuran, yaitu support dan confidence (Nafari dan Shahrabi, 2010). Parameter support adalah proporsi transaksi yang mengandung produk yang menjadi objek perhatian dalam kumpulan data, sedangkan parameter confidence adalah tingkat kepastian yang berhubungan dengan pola yang diamati (Annie dan Kumar, 2012). Pada umumnya, terdapat nilai batas minimum untuk dua parameter tersebut, disebut sebagai minimum support threshold dan minimum confidence threshold. Dua nilai minimum ini akan menjadi penentu apakah hubungan dapat dikategorikan penting atau tidak (Han dkk., 2012). Metode yang digunakan untuk melakukan pencarian terhadap produk yang memiliki frekuensi transaksi yang tinggi (frequent itemset) adalah algoritma apriori (Han dkk., 2012). Algoritma ini akan digunakan untuk menentukan jenis frequent itemset pada tahap pertama dan selanjutnya membangkitkan hubungan yang kuat dari frequent itemset.

\subsection{Dasar Perancangan Fasilitas}

Perancangan tata letak fasilitas akan menghasilkan partisi-partisi ruang dalam suatu wilayah yang terdefinisikan (Foulds, 1983). Dalam proses perancangan tata letak, terdapat prosedur yang sudah dikenal berisikan analisis kuantitatif dan kualitatif (Muther, 1973). Prosedur ini dinamakan Systematic Layout Planning (SLP). Salah satu tahapan dalam SLP adalah pengaturan lokasi masing-masing departemen didasarkan pada aliran bahan diantara departemen-departemen tersebut. Bagian ini diperlukan untuk mengevaluasi hasil tata letak yang dihasilkan.Analisis kualitatif yang digunakan dalam SLP pada aktivitas ini adalah peta hubungan aktivitas (Activity Relationship Chart). Peta ini berisikan derajat hubungan antara dua departemen dengan alasan-alasan yang mendasarinya (Wignjosoebroto, 2009).

\subsection{Kepuasan Pelanggan}

Berkembangnya jumlah ritel seiring berjalannya waktu membuat konsep kepuasan pelanggan menjadi penting. Hal ini untuk menjaga market share dan menjaga eksistensi ritel tersebut. Beberapa dimensi yang umumnya digunakan untuk mendefinisikan kepuasan pelanggan adalah format retail, harga produk, keanekaragaman produk, dan pelayanan terhadap pelanggan (Huddleson dkk., 2008). Pertama, format ritel memiliki pengertian bahwa produk-produk yang disediakan akan mengikuti perkembangan kebutuhan. Kedua, harga produk juga akan menentukan pilihan calon pembeli untuk melakukan transaksi. Ketiga, keanekaragaman produk akan cenderung dapat memenuhi kebutuhan pelanggan yang bervariasi dari satu orang ke yang lain. Keempat, pelayanan terhadap pelanggan merupakan atribut penting bagi calon pembeli.

\section{METODOLOGI PENELITIAN}

Diagram alir penelitian yang digunakan sebagai pedoman tahapan dalam penelitian dijelaskan pada Gambar 1. 
Penelitian dimulai dengan melakukan studi pendahuluan mengenai relevansi untuk mengangkat masalah atau topik perihal penggunaan metode-metode keilmuan teknik industri untuk memecahkan permasalahan khususnya pada pasar tradisional, kemudian dilakukan studi mengenai berbagai literatur dan pustaka yang dapat menunjang dan memperkaya teori penelitian dan aplikasi yang dapat digunakan untuk memecahkan permasalahan. Pada tahapan ini peneliti menggunakan berbagai buku dan jurnal yang terkait dengan obyek dan metode yang diangkat dan digunakan. Tahapan pengumpulan data dilakukan dengan melakukan pengamatan terhadap barang belanjaan yang dibawa oleh pelanggan pasar tradisional ketika mereka sudah selesai melakukan transaksi dan berjalan keluar dari pasar, pada tahapan ini peneliti mencatat setiap barang yang dibeli oleh pelanggan kedalam lembar catatan. Pada tahap pengolahan data, peneliti melakukan pembatasan terhadap variabel dari data, yakni menggunakan kategori barang yang dijual di pasar sebagai pedoman, hal ini tentu akan mempengaruhi klasifikasi terhadap barang-barang yang dibeli dan dicatat oleh peneliti, hanya barang-barang yang memiliki asosiasi (minimal 2 kategori) yang akan digunakan pada tahapan olah data, XL Miner dipilih sebagai aplikasi olah data. Tahapan analisis dilakukan dengan mengamati nilai "Conf. \%" dari derajat asosiasi antar variabel dan memetakannya kedalam ARC (Activity Relationship Chart), berdasarkan keluaran ARC peneliti membuat usulan layout pasar yang baru.

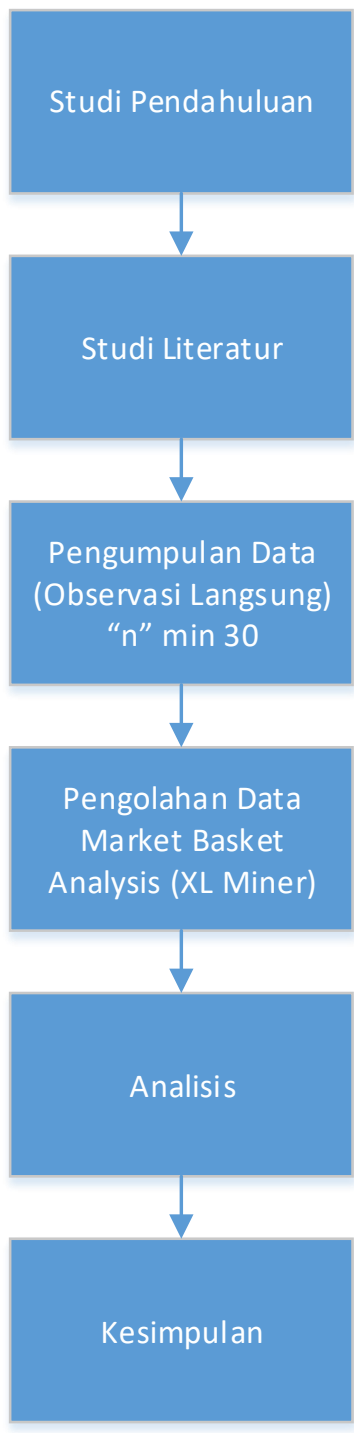

Gambar 1. Diagram Alir Penelitian

\section{ANALISIS DAN PEMBAHASAN}

\subsection{Pengolahan Data}

Data hasil observasi pengumpulan data yang diperoleh selama melakukan pengamatan dipindahkan ke dalam format excel seperti pada Tabel 1 dan Tabel 2, peneliti juga menggunakan penanda binary (1 0) sebagai syarat masukan bagi aplikasi yang digunakan, yaitu XL Miner, data transaksi yang dinyatakan valid untuk kemudian diolah data adalah bila tersedia minimal dua produk yang mewakili dua kategori, pada XL Miner kategori dinyatakan dengan var. atau variabel.

Berdasarkan pengamatan yang dilakukan pada studi pendahuluan dan observasi 
langsung saat pengumpulan data, peneliti mengklasifikasikan barang yang dijual di pasar Johar Baru kedalam sembilan (9) klasifikasi, yakni : Sayuran (Var. 1), buahbuahan (Var. 2), daging sapi (Var. 3), ikan dan makanan laut (Var. 4), sembako (Var. 5), tahu dan tempe (Var. 6), kelapa parut (Var. 7), makanan ringan (Var. 8), makanan olahan (Var. 9). Parameter dari derajat asosiasi antar variabel adalah nilai "conf. \%" (pada Tabel 3).

\subsection{Analisis Data}

Berdasarkan nilai "conf.\%" pada tabel keluaran XL Miner, selanjutnya peneliti merumuskan derajat kedekatan dan memetakannya dengan menggunakan ARC
(Activity Relationship Chart), beberapa kategori produk yang dijual dipasar perlu diletakkan mutlak berdekatan (A), seperti "sayuran dan sembako", dan "daging sapi dan sembako", sayuran dan buah-buahan memiliki derajat sangat penting untuk didekatkan (E), sayuran dan daging sapi serta sayuran dan tahu tempe memiliki derajat penting untuk didekatkan (I), sembako dan makanan memiliki derajat cukup (O). Ada juga kategori yang tidak begitu penting untuk didekatkan yakni "sayuran dan kelapa parut" dan "buahbuahan dan kelapa parut". Gambar 2 memperlihatkan hubungan antar kategori dengan menggunakan ARC.

Tabel 1. Rekapitulasi Transaksi

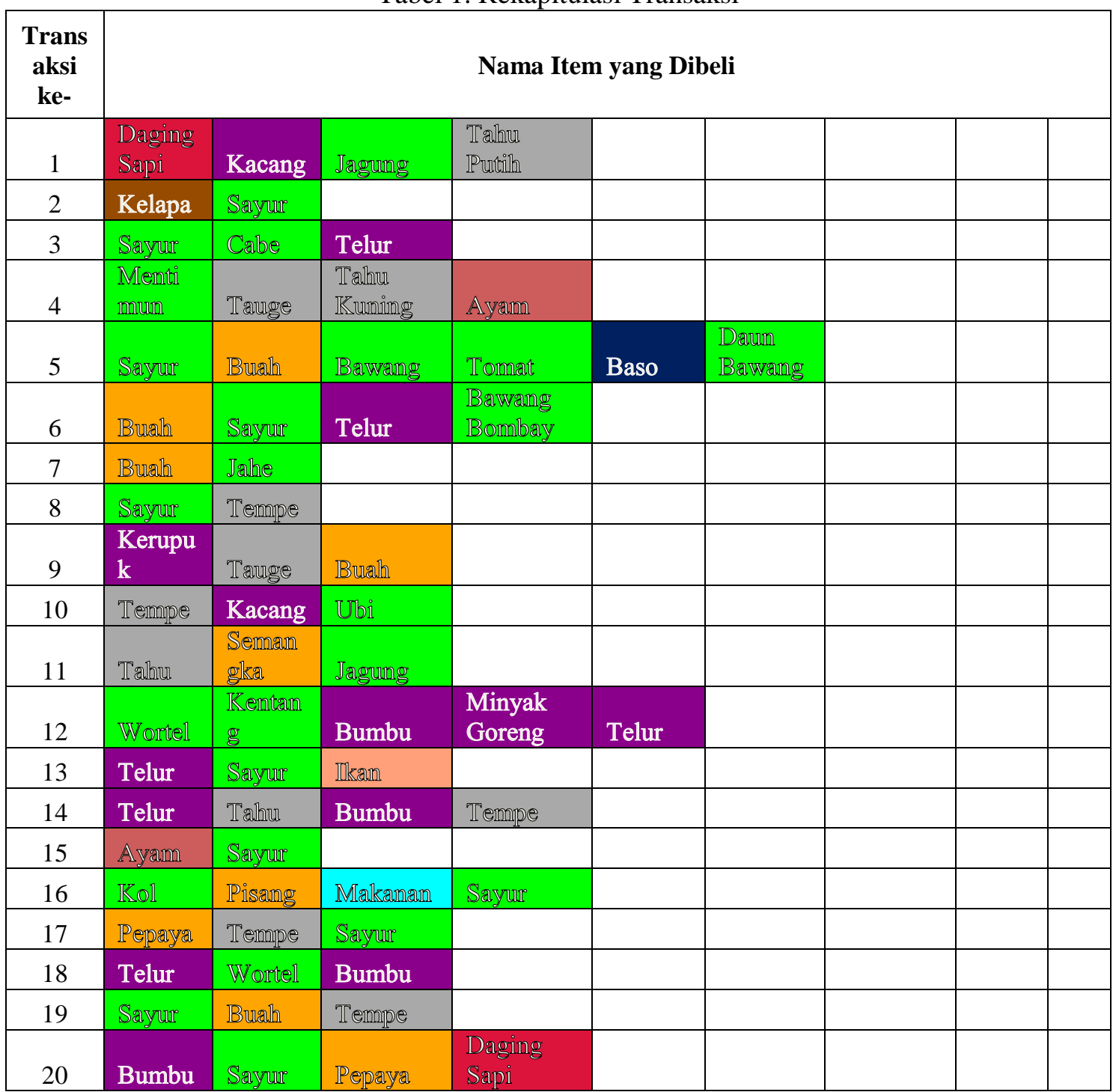


ISSN: 1979-1720 Journal of Industrial Engineering and Management Systems Vol. 10, No. 1, February 2017

\begin{tabular}{|c|c|c|c|c|c|c|c|c|c|}
\hline $\begin{array}{c}\text { Trans } \\
\text { aksi }\end{array}$ & & & & Nama Ite & n yang Di & & & & \\
\hline 21 & Pisang & Tauge & Sawi & & & & & & \\
\hline 22 & Sayure & Bumbu & Tempe & & & & & & \\
\hline 23 & Ayam & Wortell & Telur & & & & & & \\
\hline 24 & Tempe & Sayur & $\begin{array}{l}\text { Minyak } \\
\text { Goreng }\end{array}$ & Donat & & & & & \\
\hline 25 & $\begin{array}{l}\text { Mie } \\
\text { Kuning }\end{array}$ & Tempe & $\begin{array}{l}\text { Daging } \\
\text { Sapi }\end{array}$ & Jerulk & & & & & \\
\hline 26 & Telur & Bumbu & $\begin{array}{l}\text { Kue } \\
\text { Kering }\end{array}$ & & & & & & \\
\hline 27 & Telur & $\begin{array}{l}\text { Daging } \\
\text { Sapi }\end{array}$ & $\begin{array}{l}\text { Kure } \\
\text { Kerring }\end{array}$ & Ikan Asin & & & & & \\
\hline 28 & $\begin{array}{l}\text { Bawan } \\
g \\
\end{array}$ & $\begin{array}{l}\text { Daging } \\
\text { Sapi }\end{array}$ & Thain & Bumbu & Wortel & & & & \\
\hline 29 & Pisang & Tepung & Ubi & Burah & & & & & \\
\hline 30 & $\begin{array}{l}\text { Menti } \\
\text { monum }\end{array}$ & $\begin{array}{l}\text { Ikan } \\
\text { Teri }\end{array}$ & & & & & & & \\
\hline 31 & \begin{tabular}{|l|} 
Mentiti \\
manum
\end{tabular} & Pisang & Malkainam & Pete & jaguing & Tomat & Kelapa & $\begin{array}{l}\text { Ikan } \\
\text { Asin }\end{array}$ & $\begin{array}{l}\text { Tel } \\
\text { ur }\end{array}$ \\
\hline 32 & $\begin{array}{l}\text { Daging } \\
\text { Sapi }\end{array}$ & Pisang & Telur & Sayure & Bumbu & & & & \\
\hline 33 & Talnus & Telur & Sayure & Templpe & Bumbu & & & & \\
\hline 34 & Tlkain & Tomat & Tempe & & & & & & \\
\hline 35 & Sayure & Mie & Bumbu & Buralh & $\begin{array}{l}\text { KKue } \\
\mathbb{K} \text { Kering }\end{array}$ & & & & \\
\hline 36 & Namas & $\begin{array}{l}\text { Kerupu } \\
\text { k }\end{array}$ & $\begin{array}{l}\text { Kue } \\
\mathbb{K} \text { Kering }\end{array}$ & & & & & & \\
\hline 37 & Sayure & Tempe & & & & & & & \\
\hline 38 & $\begin{array}{l}\text { Bawan } \\
8\end{array}$ & Bumbu & telur & & & & & & \\
\hline 39 & $\begin{array}{l}\text { Daging } \\
\text { Sapi }\end{array}$ & Tahus & Jagung & Bumbu & Tempe & Sayur & $\begin{array}{l}\text { Minyak } \\
\text { Goreng }\end{array}$ & & \\
\hline 40 & Sayure & Buralh & & & & & & & \\
\hline 41 & Telur & $\begin{array}{l}\text { Bawwan } \\
g\end{array}$ & Jagung & Sayur & $\begin{array}{l}\text { Kelapa } \\
\text { Parut }\end{array}$ & $\begin{array}{l}\text { Kue } \\
\text { Kerring }\end{array}$ & Baso & & \\
\hline 42 & Sayure & $\begin{array}{l}\text { Bawam } \\
8\end{array}$ & ITkain & & & & & & \\
\hline 43 & Cabe & Burah & Telur & Kerupuk & & & & & \\
\hline 44 & $\begin{array}{l}\text { Daging } \\
\text { Sapi }\end{array}$ & ITkam & Talbu & \begin{tabular}{|l} 
Kelapa \\
Parut \\
\end{tabular} & & & & & \\
\hline 45 & $\begin{array}{l}\text { Bawan } \\
g\end{array}$ & Bumbu & & & & & & & \\
\hline 46 & Sayure & Buralh & & & & & & & \\
\hline 47 & $\begin{array}{l}\text { Daging } \\
\text { Sapi }\end{array}$ & $\begin{array}{l}\text { Kentain } \\
\mathrm{g}\end{array}$ & Sayurir & Bumbu & & & & & \\
\hline 48 & Sayur & Bumbu & Tomat & & & & & & \\
\hline 49 & Buralh & $\begin{array}{l}\text { Malkain } \\
\text { an }\end{array}$ & & & & & & & \\
\hline 50 & Buralh & Tempe & Bawaing & \begin{tabular}{|l|} 
Kue \\
$\mathbb{K}$ erring
\end{tabular} & & & & & \\
\hline
\end{tabular}


ISSN: 1979-1720 Journal of Industrial Engineering and Management Systems

Vol. 10, No. 1, February 2017

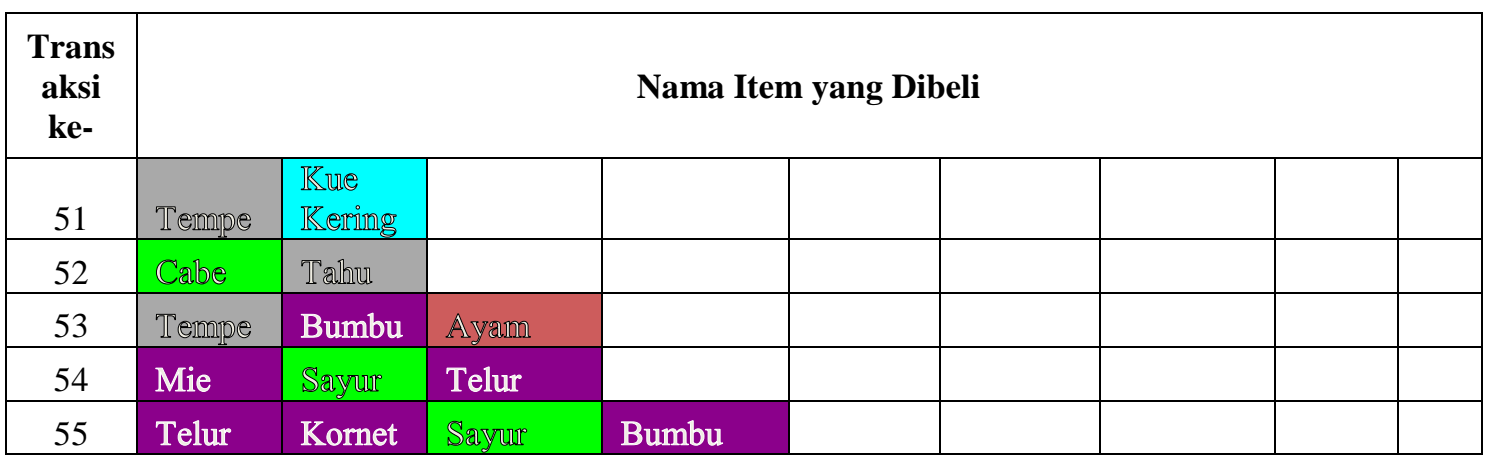

Tabel 2. Rekapitulasi Transaksi Biner

\begin{tabular}{|c|c|c|c|c|c|c|c|c|c|c|}
\hline \multirow{2}{*}{$\begin{array}{c}\text { Tran } \\
\text { saksi } \\
\text { ke- }\end{array}$} & \multicolumn{10}{|c|}{ Kategori Item yang Dibeli } \\
\hline & $\begin{array}{l}\text { Say } \\
\text { uran }\end{array}$ & $\begin{array}{l}\text { Buah- } \\
\text { buahan }\end{array}$ & $\begin{array}{l}\text { Ay } \\
\text { am }\end{array}$ & $\begin{array}{l}\text { Dagin } \\
\text { g Sapi }\end{array}$ & $\begin{array}{l}\text { Ik } \\
\text { an }\end{array}$ & $\begin{array}{l}\text { Sem } \\
\text { bako }\end{array}$ & $\begin{array}{l}\text { Tahu \& } \\
\text { Tempe }\end{array}$ & $\begin{array}{l}\text { Kel } \\
\text { apa }\end{array}$ & $\begin{array}{l}\text { Mak } \\
\text { anan }\end{array}$ & $\begin{array}{l}\text { Makanan } \\
\text { Olahan }\end{array}$ \\
\hline 1 & 1 & 0 & 0 & 1 & 0 & 1 & 1 & 0 & 0 & 0 \\
\hline 2 & 1 & 0 & 0 & 0 & 0 & 0 & 0 & 1 & 0 & 0 \\
\hline 3 & 1 & 0 & 0 & 0 & 0 & 1 & 0 & 0 & 0 & 0 \\
\hline 4 & 1 & 0 & 1 & 0 & 0 & 0 & 1 & 0 & 0 & 0 \\
\hline 5 & 1 & 1 & 0 & 0 & 0 & 0 & 0 & 0 & 0 & 1 \\
\hline 6 & 1 & 1 & 0 & 0 & 0 & 1 & 0 & 0 & 0 & $\underline{0}$ \\
\hline 7 & 1 & 1 & 0 & 0 & 0 & 0 & 0 & 0 & 0 & 0 \\
\hline 8 & 1 & 0 & 0 & 0 & 0 & 0 & 1 & 0 & 0 & 0 \\
\hline 9 & 0 & 1 & 0 & 0 & 0 & 1 & 1 & 0 & 0 & 0 \\
\hline 10 & 1 & 0 & 0 & 0 & 0 & 1 & 1 & 0 & 0 & 0 \\
\hline 11 & 1 & 1 & 0 & 0 & 0 & 0 & 1 & 0 & 0 & 0 \\
\hline 12 & 1 & 0 & 0 & 0 & 0 & 1 & 0 & 0 & 0 & 0 \\
\hline 13 & 1 & 0 & 0 & 0 & 1 & 1 & 0 & 0 & 0 & 0 \\
\hline 14 & 0 & 0 & 0 & 0 & 0 & 1 & 1 & 0 & 0 & 0 \\
\hline 15 & 1 & 0 & 1 & 0 & 0 & 0 & 0 & 0 & 0 & 0 \\
\hline 16 & 1 & 1 & 0 & 0 & 0 & 0 & 0 & 0 & 1 & 0 \\
\hline 17 & 1 & 1 & 0 & 0 & 0 & 0 & 1 & 0 & 0 & 0 \\
\hline 18 & 1 & 0 & 0 & 0 & 0 & 1 & 0 & 0 & 0 & 0 \\
\hline 19 & 1 & 1 & 0 & 0 & 0 & 0 & 1 & 0 & 0 & 0 \\
\hline 20 & 1 & 1 & 0 & 1 & 0 & 1 & 0 & 0 & 0 & 0 \\
\hline 21 & 1 & 1 & 0 & 0 & 0 & 0 & 1 & 0 & 0 & 0 \\
\hline 22 & 1 & 0 & 0 & 0 & 0 & 1 & 1 & 0 & 0 & 0 \\
\hline 23 & 1 & 0 & 1 & 0 & 0 & 1 & 0 & 0 & 0 & 0 \\
\hline 24 & 1 & 0 & 0 & 0 & 0 & 1 & 1 & 0 & 1 & 0 \\
\hline 25 & 0 & 1 & 0 & 1 & 0 & 1 & 1 & 0 & 0 & 0 \\
\hline 26 & 0 & 0 & 0 & 0 & 0 & 1 & 0 & 0 & 1 & 0 \\
\hline 27 & 0 & 0 & 0 & 1 & 0 & 1 & 0 & 0 & 1 & 0 \\
\hline 28 & 1 & 0 & 0 & 1 & 1 & 1 & 0 & 0 & 0 & 0 \\
\hline 29 & 1 & 1 & 0 & 0 & 0 & 1 & 0 & 0 & 0 & 0 \\
\hline 30 & 1 & 0 & 0 & 0 & 0 & 1 & 0 & 0 & 0 & 0 \\
\hline
\end{tabular}


ISSN: 1979-1720 Journal of Industrial Engineering and Management Systems Vol. 10, No. 1, February 2017

\begin{tabular}{|c|c|c|c|c|c|c|c|c|c|c|}
\hline \multirow{2}{*}{$\begin{array}{c}\text { Tran } \\
\text { saksi } \\
\text { ke- }\end{array}$} & \multicolumn{10}{|c|}{ Kategori Item yang Dibeli } \\
\hline & $\begin{array}{l}\text { Say } \\
\text { uran }\end{array}$ & $\begin{array}{l}\text { Buah- } \\
\text { buahan }\end{array}$ & $\begin{array}{l}\text { Ay } \\
\text { am }\end{array}$ & $\begin{array}{l}\text { Dagin } \\
\text { g Sapi }\end{array}$ & $\begin{array}{l}\text { Ik } \\
\text { an }\end{array}$ & $\begin{array}{l}\text { Sem } \\
\text { bako }\end{array}$ & $\begin{array}{l}\text { Tahu \& } \\
\text { Tempe }\end{array}$ & $\begin{array}{l}\text { Kel } \\
\text { apa }\end{array}$ & $\begin{array}{l}\text { Mak } \\
\text { anan }\end{array}$ & $\begin{array}{l}\text { Makanan } \\
\text { Olahan }\end{array}$ \\
\hline 31 & 1 & 1 & 0 & 0 & 0 & 1 & 0 & 1 & 1 & 0 \\
\hline 32 & 1 & 1 & 0 & 1 & 0 & 1 & 0 & 0 & 0 & 0 \\
\hline 33 & 1 & 0 & 0 & 0 & 0 & 1 & 1 & 0 & 0 & 0 \\
\hline 34 & 1 & 0 & 0 & 0 & 1 & 0 & 1 & 0 & 0 & 0 \\
\hline 35 & 1 & 1 & 0 & 0 & 0 & 1 & 0 & 0 & 1 & 0 \\
\hline 36 & 0 & 1 & 0 & 0 & 0 & 1 & 0 & 0 & 1 & 0 \\
\hline 37 & 1 & 0 & 0 & 0 & 0 & 0 & 1 & 0 & 0 & 0 \\
\hline 38 & 1 & 0 & 0 & 0 & 0 & 1 & 0 & 0 & 0 & 0 \\
\hline 39 & 1 & 0 & 0 & 1 & 0 & 1 & 1 & 0 & 0 & 0 \\
\hline 40 & 1 & 1 & 0 & 0 & 0 & 0 & 0 & 0 & 0 & 0 \\
\hline 41 & 1 & 0 & 0 & 0 & 0 & 1 & 0 & 1 & 1 & 1 \\
\hline 42 & 1 & 0 & 0 & 0 & 1 & 0 & 0 & 0 & 0 & 0 \\
\hline 43 & 1 & 1 & 0 & 0 & 0 & 1 & 0 & 0 & 0 & 0 \\
\hline 44 & 0 & 0 & 0 & 1 & 1 & 0 & 1 & 1 & 0 & 0 \\
\hline 45 & 1 & 0 & 0 & 0 & 0 & 1 & 0 & 0 & 0 & 0 \\
\hline 46 & 1 & 1 & 0 & 0 & 0 & 0 & 0 & 0 & 0 & 0 \\
\hline 47 & 1 & 0 & 0 & 1 & 0 & 1 & 0 & 0 & 0 & 0 \\
\hline 48 & 1 & 0 & 0 & 0 & 0 & 1 & 0 & 0 & 0 & 0 \\
\hline 49 & 0 & 1 & 0 & 0 & 0 & 0 & 0 & 0 & 1 & 0 \\
\hline 50 & 1 & 1 & 0 & 0 & 0 & 0 & 1 & 0 & 1 & 0 \\
\hline 51 & 0 & 0 & 0 & 0 & 0 & 0 & 1 & 0 & 1 & 0 \\
\hline 52 & 1 & 0 & 0 & 0 & 0 & 0 & 1 & 0 & 0 & 0 \\
\hline 53 & 0 & 0 & 1 & 0 & 0 & 1 & 1 & 0 & 0 & 0 \\
\hline 54 & 1 & 0 & 0 & 0 & 0 & 1 & 0 & 0 & 0 & 0 \\
\hline 55 & 1 & 0 & 0 & 0 & 0 & 1 & 0 & 0 & 0 & 0 \\
\hline
\end{tabular}

Tabel 3. Hasil Pengolahan Data dengan XL Miner

\begin{tabular}{|r|r|l|l|r|r|r|r|}
\hline Rule \# & $\begin{array}{r}\text { Conf. } \\
\%\end{array}$ & Antecedent (a) & $\begin{array}{l}\text { Consequent } \\
\text { (c) }\end{array}$ & Support(a) & Support(c) & $\begin{array}{r}\text { Support(a U } \\
\text { c) }\end{array}$ & Lift Ratio \\
\hline 1 & 100 & Var1, Var4=> & Var6 & 6 & 34 & 6 & 1.617647 \\
2 & 88.89 & Var4=> & Var6 & 9 & 34 & 8 & 1.437908 \\
3 & 54.55 & Var9=> & Var2 & 11 & 21 & 6 & 1.428571 \\
4 & 66.67 & Var4=> & Var1, Var6 & 9 & 27 & 6 & 1.358025 \\
5 & 63.64 & Var9=> & Var6 & 11 & 34 & 7 & 1.029412 \\
6 & 80.95 & Var2=> & Var1 & 21 & 45 & 17 & 0.989418 \\
7 & 79.41 & Var6=> & Var1 & 34 & 45 & 27 & 0.970588 \\
8 & 60 & Var1=> & Var6 & 45 & 34 & 27 & 0.970588 \\
9 & 75 & Var4, Var6=> & Var1 & 8 & 45 & 6 & 0.916667 \\
10 & 72.73 & Var7=> & Var1 & 22 & 45 & 16 & 0.888889 \\
11 & 70 & Var2, Var6=> & Var1 & 10 & 45 & 7 & 0.855556 \\
12 & 66.67 & Var4=> & Var1 & 9 & 45 & 6 & 0.814815 \\
13 & 60 & Var6, Var7=> & Var1 & 10 & 45 & 6 & 0.733333 \\
14 & 54.55 & Var9=> & Var1 & 11 & 45 & 6 & 0.666667 \\
\hline
\end{tabular}




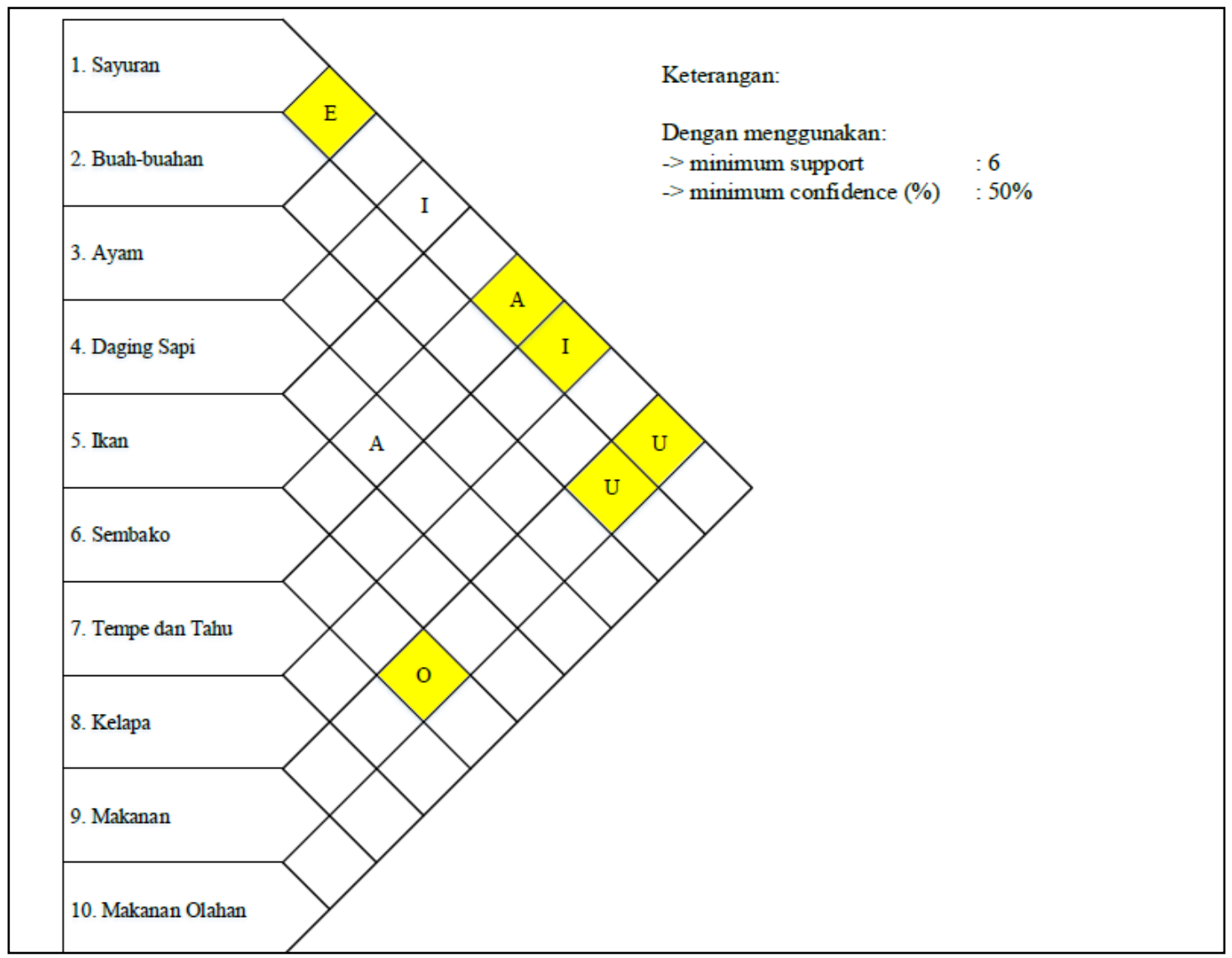

Gambar 2. Analisis dengan ARC

\subsection{Layout Sekarang dan Layout Usulan} Dengan mempertimbangkan hasil analisis hubungan antar kategori yang terdapat pada ARC, kemudian peneliti membuat usulan layout dengan harapan dapat mengurangi kepadatan lalu-lintas di pasar Johar Baru dan berdampak pada kepuasan pelanggan, khususnya pelanggan pasar Johar Baru. Untuk melihat hasil perbaikan tata letak dari layout yang ada saat ini dibandingkan dengan layout yang diusulkan oleh peneliti, ditampilkan dua layout, yakni layout saat ini (Gambar 3) dan layout usulan (Gambar 4).

Langkah perbaikan terhadap layout yang dilakukan peneliti adalah dengan mengelompokkan penjual sayuran yang semula tersebar di 17 blok meja menjadi 9 blok meja dan ditempatkan di sisi selatan pasar, mengelompokkan penjual buahbuahan yang semula tersebar di 9 blok meja menjadi 4 blok meja dan ditempatkan di sisi selatan pasar, mengelompokkan penjual ayam yang semula tersebar di 7 blok meja menjadi 5 blok meja dan ditempatkan di sisi barat pasar, mengelompokkan penjual daging yang semula tersebar di 5 blok meja menjadi 4 blok meja dan ditempatkan di sisi utara pasar, mengelompokkan penjual ikan yang semula tersebar di 7 blok meja menjadi 4 blok meja dan ditempatkan di bagian barat pasar, mengelompokkan penjual sembako yang semula tersebar di 13 blok meja menjadi 6 blok meja dan ditempatkan di bagian timur pasar, mengelompokkan penjual tahu dan tempe yang semula tersebar di 7 blok meja menjadi 3 blok meja dan ditempatkan di bagian timur pasar, mengelompokkan penjual kelapa yang semula tersebar di 3 blok meja menjadi 2 blok meja dan ditempatkan di bagian utara pasar, mengelompokkan penjual makanan yang semula tersebar di 8 blok meja menjadi 5 blok meja dan ditempatkan di bagian timur pasar, dan mengelompokkan penjual makanan olahan yang semula tersebar di 4 blok meja menjadi 2 blok meja dan ditempatkan di bagian utara pasar. 


\section{JIEMS}

ISSN: 1979-1720 Journal of Industrial Engineering and Management Systems Vol. 10, No. 1, February 2017

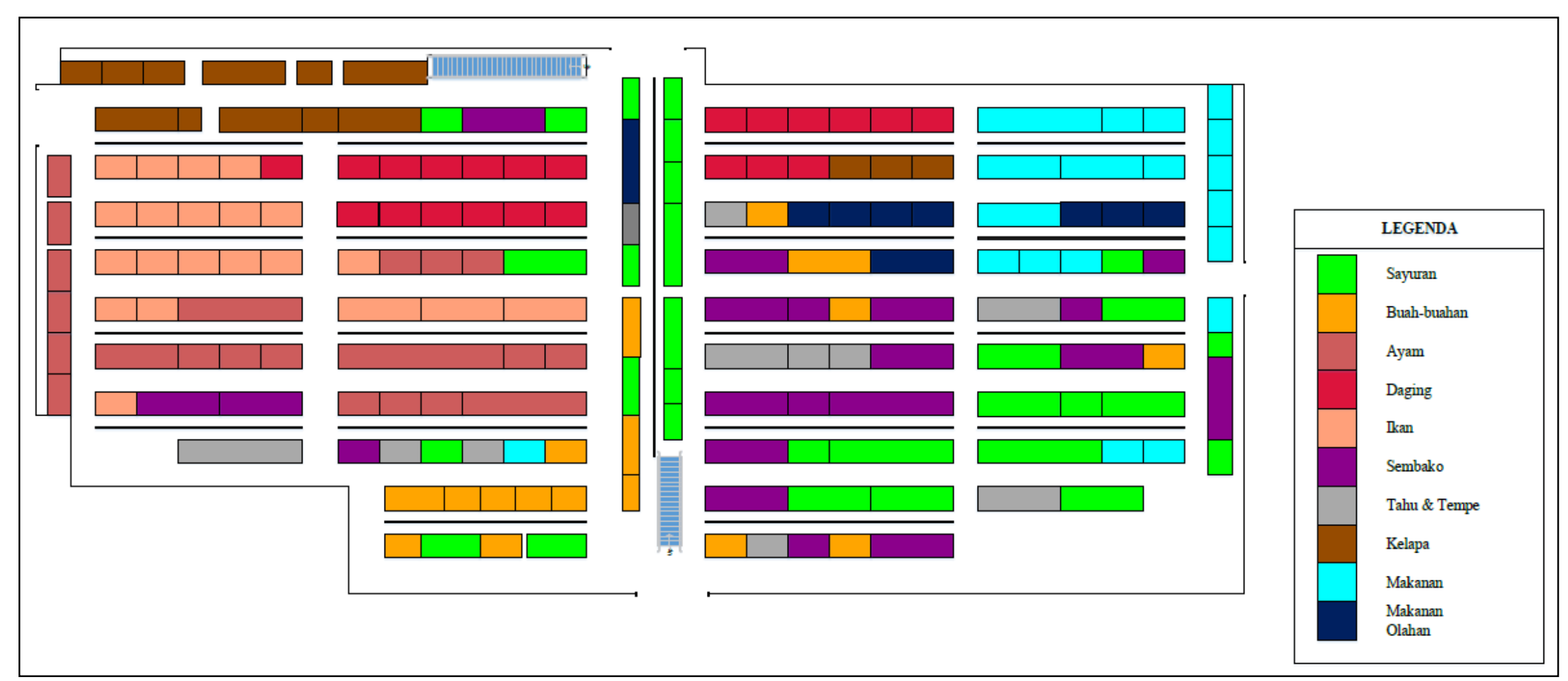

Gambar 3. Layout Sekarang 
JIEMS

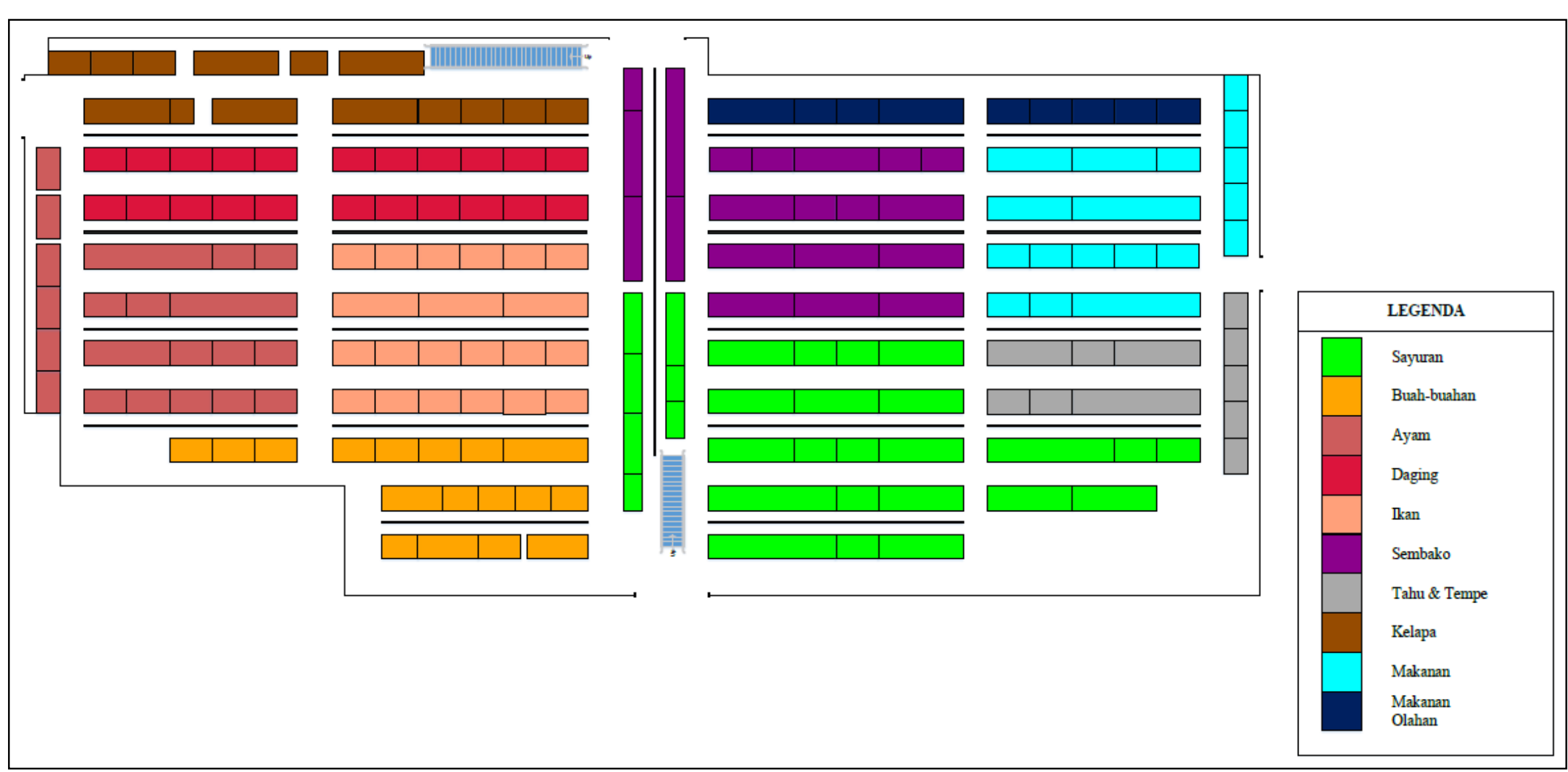

Gambar 4. Layout Usulan 


\section{KESIMPULAN}

Berikut adalah beberapa kesimpulan yang diperoleh setelah melakukan penelitian:

1. Posisi penjual Sayuran dan Sembako adalah mutlak berdekatan (A)

2. Posisi penjual Daging Sapi dan Sembako adalah mutlak berdekatan (A)

3. Posisi penjual Sayuran dan Buah-buahan adalah sangat penting untuk didekatkan (E)

4. Posisi penjual Sayuran dan Daging Sapi adalah penting untuk didekatkan (I)

5. Posisi penjual Sayuran dan Tahu Tempe adalah penting untuk didekatkan (I)

6. Posisi penjual Sembako dan Makanan adalah cukup untuk didekatkan (O)

7. Posisi penjual Sayuran dan Makanan adalah tidak penting atau tidak perlu didekatkan (U)

8. Posisi penjual Buah-buahan dan Makanan adalah tidak penting atau tidak perlu didekatkan (U)

\section{DAFTAR PUSTAKA}

1. Annie, Loraine, C., dan Kumar, A.D. (2012). "Market Basket Analysis for a Supermarket based on Frequent Itemset Mining". International Journal of Computer Science Issues, Vol. 9 Issue 5, No. 3.

2. Bermudez, Jonathan, Apolinario, K., dan Andres G.A. (2016). "Layout Optimization and Promotional Strategies Design in a Retail Store based on a Market Basket Analysis". 14th LACCEI International Multi-Conference for Engineering, Education, and Technology.

3. Christina, N.R. dan Liem, Y B. (2014). "Penentuan Lokasi dan Perancangan Tata Letak Fasilitas Tempat Packaging PT.ABC". Jurnal Titra. Vol. 2 No. 2, pp. 65-70.

4. Farieza, Q., Fifi H.M., dan Susy, S. (2014). "Rancangan Tata Letak Fasilitas Bagian Produksi Pada CV. Visa Insan Madani”. Jurnal Reka Integra. Vol. 3 No. 1, pp. 1-13.

5. Fornell, C. (1992). "A National Customer Satisfaction Barometer: The Swedish Experience". Journal of Marketing, Vol. 56.
6. Foulds, L.R. (1983). "Techniques for Facilities Layout: Deciding Which Pairs of Activities Should be Adjacent". Management Science, Vol. 29 No. 12.

7. Han, J., Micheline K., dan Jian, P. (2012). Data Mining: Concepts and Techniques. Elsevier. Waltham.

8. Hand, David, Heikki, M., dan Padhraic S. (2001). Principles of Data Mining. MIT Press: Cambridge.

9. Huddleson, Patricia, Judith, W., Rachel, N.M., dan So, J.L. (2009). "Customer Satisfaction in Food Retailing: Comparing Specialty and Conventional Grocery Stores". International Journal of Retail and Distribution Management, Vol. 37 No. 1.

10.http://www.marketing.co.id/brandswitching-analysis-dalam-industri-ritelmodern/ (diakses pada 15 September 2016).

11.Larose, D.T. (2005). Discovering Knowledge in Data: An Introduction to Data Mining. John Wiley \& Sons: New Jersey.

12.Lusiani, M. (2011). Optimasi Alokasi Produk pada Ruang Rak Displai Gerai Minimarket berdasarkan Harga Produk Menggunakan Multilevel Association Rules. Tesis. Universitas Indonesia: Depok.

13.Nafari, M. dan Shahrabi, J. (2010). "A Temporal Data Mining Approach for Shelf-Space Allocation with Consideration of Product Price". Expert Systems with Application, Vol. 37, pp. 4066-4072.

14.Peraturan Presiden Republik Indonesia Nomor 112 Tahun 2007 Tentang Penataan dan Pembinaan Pasar Tradisional, Pusat Perbelanjaan dan Toko Modern.

15.Pradana, E. dan Cahyono B.N. (2014). "Analisis Tata Letak Fasilitas Proyek Menggunakan Activity Relationship Chart dan Multi-Objectives Function pada Proyek Pembangunan Apartemen De Papilio Surabaya”. Jurnal Teknik Pomits. Vol. 3 No. 2, pp. D131-D136. 
ISSN: 1979-1720 Journal of Industrial Engineering and Management Systems

Vol. 10, No. 1, February 2017

16.Surjandari, I. dan Seruni, A.C. (2005). "Design of Product Placement Layout in Retail Shop using Market Basket Analysis". Makara Teknologi, Vol. 9 No. 2.

17.Wignjosoebroto, S. (2009). Tata Letak Pabrik dan Pemindahan Bahan. Edisi Ketiga. Guna Widya: Surabaya. 